\title{
Primeiro Discurso sobre a educação cristã $\tilde{a}^{*}$
}

\section{João Leon Dehon}

Sua finalidade - seus instrumentos - seu método - seus frutos*

Senhores,

Nós nos apresentamos a vocês como homens de educação. Sentimos toda importância da obra que empreendemos. Compreendemos toda nossa responsabilidade frente aos pais e mães de família que nos confiarão o que eles têm de mais caro frente a sociedade da qual vamos formar alguns membros escolhidos, diante de Deus, que tanto ama a infância e quer seja tratada com o soberano respeito.

Esta importância da educação, aliás, é uma verdade de senso comum. O céu a proclamou pela Sagrada Escritura, e todos os ecos da terra o repetiram.

"É um proverbio, dizia Salomão, que o homem segue durante toda sua vida o caminho de sua juventude"1

Platão dizia: "os começos representam tudo numa natureza jovem e terna que guarda para sempre o molde inicial"2.

E Leibniz: "Eu sempre pensei que o gênero humano seria reformado, contanto que a educação fosse reformada"3.

Basta citar esses dois filósofos entre mil outros.

O problema da educação apaixonou todas as gerações. Sempre tivera sobre os espíritos um irresistível atrativo. Não existe pensador que não tenha apresentado sua visão a respeito da educação. Nela, os filósofos buscaram o meio de moralização, os

\footnotetext{
* Premier Discurs de l'education chretienne, in Oeuvres Sociales, Thèses et Discours 1862-1901, V. IV, Edizioni Dehoniane, Napoli/Andria/Roma, 1985, pp.274/293 trad. Marie Thérèse Cance. A tradutora optou por indicar entre colchetes as transições de páginas na edição original.

*Discurso pronunciado na "Maison d'Enseignement de Saint Quentin", no dia 4 de agosto de 1877. V. e.

“La semaine Religieuse du Diocèse de Soissons et Laon”, 4 ano, 1877, p. 440, Saint Quentin. Institution Saint-Jean..

${ }^{1}$ Provérbio XXII, 6 "Proverbium est: adolescens juxta viam suam, etiam cum senuerit, non recedet ab eà"

${ }^{2}$ Rep. livro II, cp. XVII

${ }^{3}$ E. Dutens, t. VI, p. 65
} 
políticos um meio de influência. Todas as legislações tentaram organizá-la e orientá-la. Não há matéria ${ }_{2741}$ que tenha sito tratada por um maior número de escritores ${ }^{4}$.

Vocês esperam de nós uma profissão de fé sobre a educação e o ideal que temos dela a respeito de seus instrumentos, do método que tem nossas preferências, nos frutos que se deve esperar; vamos fazer uma exposição leal.

O que é, portanto, essa importante obra da educação e qual a sua finalidade?

Um homem do mundo, daqueles que vivem fora do nosso meio cristão e que não tem um ideal elevado me responderia: "a educação, é a aquisição dos conhecimentos necessários para se apresentar com sucesso a um exame, para iniciar uma profissão e se fazer uma reputação de homem culto. É, ainda, a formação ao saber viver, ao bom tom, às boas maneiras, numa palavra, a tudo que é necessário para fazer seu caminhar neste mundo".

Tudo isso é bom, mas é só isso?

Eis agora o pensamento cristão traduzido na linguagem elevada e poética de um dos bispos mais eloquentes destes séculos. ${ }^{5}$

“Todo cristão batizado é uma flor divina ou, antes, um deus florido; cada um de seus atos deve ser um passo em direção à maturidade, à idade perfeita, até à grandeza e à altura divina.

Filhos do batismo, da primeira comunhão, a Igreja sua Mãe lhes sugeriu pretensões imensas, mostrou-lhes sua natureza divina inspirou-lhes ódios sagrados contra o mal, contra a paixão, contra o demônio.

O verdadeiro cristão não se situa eminentemente acima de um homem que seria apenas rei? Não deve ele ter uma alma maior, fazer ações mais nobres, usar uma coroa mais bela? Portanto que ele seja instruído desde sua mais terna infância ou fazê-lo instruir, cada dia, a respeito da grandeza de seu destino. Cuide para que não deixe arrastar seu pensamento e seus desejos. Que seja revestido daquelas virtudes

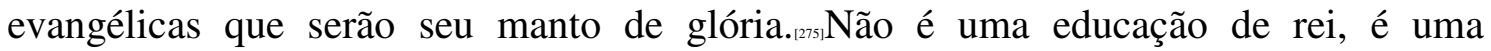

\footnotetext{
${ }^{4}$ Um dicionário de pedagogia enumera mais de duas mil obras de educação publicadas em francês, Buisson, livraria Hachette.

${ }^{5}$ Dom Berthaud, Bispo de Tulle.
} 
educação divina que se precisa para elevar a toda sua altura aquele que deve ser a imagem de Deus no caminho da perfeição e seu convidado para o banquete da eterna felicidade."

Expressemos com mais simplicidade estas grandes coisas.

Na base de todo sistema de educação, há um pensamento dominante e essencial, uma finalidade, um ideal. Esta finalidade sempre se relaciona com as doutrinas políticas e religiosas do filósofo que concebe este sistema de educação ou da sociedade que o estabelece. À orientação dada à educação, depende de um modo particular da ideia que se tem do homem perfeito. A imensa superioridade da educação cristã sobre qualquer outra, provém do fato que sua finalidade e seu ideal consistem na perfeição total e sobrenatural do homem nesta e na outra vida.

Platão, no mundo grego, tinha entrevisto esta nobre finalidade. Ele deu a mais bela definição da educação: "eu chamo educação, dizia ele, o que dá ao corpo e à alma toda beleza e toda perfeição de que são capazes". ${ }^{6}$ E nesta perfeição da alma, ele não tinha somente em vista a vida presente. "É uma loucura, para uma criatura mortal, disse ele, ainda falando da educação, ter mais preocupação com essa curta existência do que com a eternidade". ${ }^{7}$ Mas essa visão elevada de Platão foi excepcional e permaneceu um ideal sem realidade.

Para compreender melhor o ideal cristão e torná-lo mais claro, perguntemos à história o que ela nos oferece, fora desse ideal.

Houve o ideal dos povos primitivos, o ideal de Esparta, o de Roma, antes das guerras púnicas. Para estes povos, o homem perfeito é o soldado valente, que suporta o cansaço, que aceita a disciplina. Para eles, a educação quase que se reduz ao desenvolvimento das forças físicas e à habilidade do corpo.

Houve o ideal político. É o ideal dos poderes implantados pela força e que querem prevenir sua descrença nos espíritos. Foi o da Convenção em 1792. A política se torna então, a preocupação quase exclusiva dos organizadores da educação nacional. Tudo mais, religião, delicadeza dos costumes, cultura do espirito, nobreza do coração, é totalmente desprezado ou deixado em segundo plano. $\mathrm{O}$ homem parece ser apenas um animal político, que veio ao mundo para conhecer, amar e servir a constituição. A

${ }^{7}$ Diálogo Fédon 
Declaração dos direitos do homem ${ }_{2270}$ já era para Talleyrand, o catecismo da infância. ${ }^{8}$ Para Lepelletier de Saint-Fargeau, Barrère, Danton, e para a Convenção que os aprova, a família deve renunciar a seus direitos frente ao Estado. As crianças pertencem à grande família social antes de pertencer à sua família privada. ${ }^{9}$

Nesta base, se organizava sistemas que gostamos de reler nem que seja como divertimento. Por exemplo, a proposta era que a educação comum de todas as crianças fossem feitas longe de suas famílias, a partir da idade de cinco anos, educação que se limitava aos conhecimentos elementares e se confundia com a aprendizagem profissional, sem distinção de sexo, e até mesmo, com práticas idênticas. ${ }^{10}$

Como vocês podem ver isso não é nosso ideal.

O ideal político não foi estranho nem à organização primeira da Universidade com o seu monopólio exclusivo, sob o "Consulado e o Império".

Há ainda o ideal utilitário. É o ideal de uma numerosa escola inglesa contemporânea, a escola dos positivistas na França. Todo o desenvolvimento da pessoa humana para eles se reduz à atividade física e industrial. $\mathrm{O}$ homem é apenas um ser material. Não se trata de alma, de moral, de cultura intelectual, de religião.

Finalmente há o ideal que o chamaria de crítico, ou da arte pela arte. É o ideal de um grande número de membros do ensino oficial do nosso tempo. Eles cultivam as letras e a filosofia, mas não tem outro culto senão o da forma na literatura e na arte. Rejeitam todo princípio religioso. Para eles, Deus é apenas uma ideia e todas as religiões são evoluções progressivas do espirito humano.

Só o ideal cristão abraça ao mesmo tempo todos os elementos da perfeição humana.

A educação cristã não negligencia o que é importante para o desenvolvimento físico. Preocupa-se com a higiene e os exercícios do corpo. Considera as letras e a ciência como necessárias para desenvolver as mais essenciais faculdades do espirito. Forma o julgamento por meio da filosofia e da história, o gosto, por meio do conhecimento $_{[27]}$ dos modelos da literatura e da arte, a vontade do coração por meio da

\footnotetext{
${ }^{8}$ Assembléia Nacional, 25 de set de 1791.

${ }^{9}$ Moniteur, 22 de set. 14 de dez. de 1793.

10 Projeto de Lepelletier de Saint-Fargeau retomado e apresentado por Robespierre na Convenção (Moniteur, 15 de ago. de 1793) Michelet acha este projeto admiravelmente realista [nullement chimérique] (História da Revolução Francesa, T. IV, p. 390).
} 
religião, os costumes e o caráter por meio dos procedimentos delicados em uso na melhor sociedade.

Educar um cristão, não é apenas dar-lhe noções de ciências humanas que o ajudarão a ter uma posição na vida. Não é apenas formá-lo para uma delicada polidez, dar-lhe uma ciência profunda e fazer dele um homem que possa e queira entrar em todos os progressos do gênio humano. É igualmente e, antes de tudo, formar nele um nobre e grande caráter, costumes puros, virtudes sólidas. É fazer crescer em sua alma, a fé que abre ao entendimento do mundo invisível, a esperança que fortifica o coração pela perspectiva de uma felicidade merecida, e o amor que torna Deus sensível nas sombras frias da vida.

Educar um cristão, é ainda formar um homem de coração, um homem de sacrifícios e dedicação, um homem que tenha sacudido o jugo do egoísmo. Qualquer que seja a profissão que um dia ele abraçará, sacerdote, soldado, agricultor, industrial ou magistrado, o discípulo da educação cristão levará nela a convicção ardente e profunda de que ele deve exercer uma influência regeneradora de palavras e de exemplos.

Tudo o que Deus lhe deu como talento ou gênio, tudo o que a educação lhe comunicou de forças intelectuais e morais, tudo isso não será apenas o meio de honrar a sua vida; será ainda o instrumento do bem que deve realizar. Na esfera de ação onde a Providência o colocar, ele será o missionário da virtude e a viva imagem de Jesus Cristo.

Tal é a finalidade da educação cristã. Tal é a nossa. E se nossa expectativa for bem sucedida, nossos alunos, pelo menos os que corresponderem plenamente aos nossos cuidados, encontrarão no espirito que nós daremos na casa, no culto particular do Sagrado Coração de Jesus, e na proteção do seu amável discípulo São João, uma graça especial de pureza, de doçura, de piedade e de zelo para fazer o bem.

Tal é nosso ideal. É também o seu, não é verdade?

\section{II [Continuar aqui]}


Digamos agora o que devem ser, segundo nosso parecer, os instrumentos da educação cristã, os mestres que a distribuem, os livros que eles utilizam.

O mestre exerce, para com seu discípulo, a ação de uma verdadeira paternidade espiritual. [278] Gera verdadeiramente nele a vida e a semelhança de sua alma. A vida intelectual e moral passa da alma do educador para a alma do seu aluno por meio de duas fontes: a palavra e o exemplo. Comunica-lhe seus pensamentos. Revela-lhe a verdade tal como sua inteligência a concebe; o belo, tal como ele o compreende e soube amá-lo; o bem, tal como a sua consciência o indica.

Falar de uma tal missão, é falar de sua responsabilidade e, ao mesmo tempo, de sua nobreza. Por causa disso compreendo porque as famílias cristãs são exigentes para com aqueles que aceitam como sendo segundos pais para as almas dos seus filhos.

Não basta que eles sejam virtuosos, e a fama de homem honesto não é para eles um diploma. É preciso que eles sejam grandes cristãos afim de que as crianças sintam, de algum modo, em toda sua pessoa, o Mestre dos mestres, o CRISTO que eles representam e cuja dignidade os encobrem.

E se com tudo que acabo de supor, o mestre católico recebeu do céu uma vocação que o dedica não só à pratica do dever, mas ao heroísmo da virtude; se ele fez o juramento, não só da honestidade, mas da santidade; se acrescenta à dignidade que lhe provêm de sua missão, a grandeza da unção divina e de um caráter sagrado; oh! Então ninguém pode dizer o que vai produzir na criança, esta ação poderosa e tão elevada acima da natureza.

Com isso não se quer dizer que só o padre seja capaz de dar a infância o benefício da educação cristã. Todo homem profundamente cristão, sacerdote ou leigo, regular ou secular, basta, mas o cristão não pode negar que a dedicação especial a JESUS CRISTO, imposto pela unção do sacerdócio ou pelos votos de religião, em geral, não seja na educação, uma força e uma vantagem a mais.

Muitas vezes os educadores leigos, eles mesmos o disseram. Eis, por exemplo, alguns pensamentos expressos por um professor de Faculdade, numa obra coroada pela Academia. ${ }^{11}$ "Certamente muito deve ser dito em favor do ensino dado e dirigido por eclesiásticos ou religiosos. Nossas preferências pelo ensino leigo não nos impedem de

\footnotetext{
${ }^{11}$ G. Compayré, História crítica das doutrinas da educação na França.
} 
reconhecer as vantagens consideráveis, sobre certos pontos, que seu caráter assegura aos professores eclesiásticos. A absoluta independência em relação ao mundo, a supressão de todos os laços que unem cada um de nós à família e a sociedade civil [279] a renúncia a todo interesse terrestre, a ruptura com as paixões que perturbam, que usam as forças e devoram o tempo, a solidão e a paz que impedem a dispersão do pensamento sobre as curiosidades do mundo e os incidentes da vida, que permitem à reflexão concentrar-se em um único objeto, a elevação do pensamento necessariamente familiar a quem acredita trabalhar para a eternidade; o costume da disciplina que é mais fácil impor aos outros quando se é o primeiro a praticá-la; em fim, e acima de tudo, a força moral, a autoridade que só é maior no homem quando se esquece a si próprio para falar e agir em nome da divindade: eis as condições favoráveis em que se encontram o sacerdote ou o religioso que se torna professor".

Não poderiam se expressar melhor as vantagens do ensino eclesiástico.

Um outro professor eminente da Universidade ${ }^{12}$ elogiava da mesma maneira a aplicação, a dedicação, o zelo profissional dos padres e dos religiosos na educação, zelo sem o qual o mestre mais hábil e mais distinto não pode fazer o bem, e entre outros motivos dava o seguinte: “É difícil aproximar-se da juventude sem amá-la e é com a maior doçura para homens que romperam com sua família natural, encontram ali o que eles perderam".

Isto é bem verdadeiro. É nestas condições que chegamos até vocês. Independentes em relação ao mundo, desapegados de todo interesse pessoal, estaremos totalmente dedicados a nossa obra, aos seus filhos. Trabalhando para eles, acreditamos trabalhar para Deus. Eis os segredos de nossa dedicação, os segredos do ardor e do zelo que teremos para ajudar seus filhos na sua formação para que eles correspondam a suas expectativas e a expectativa de Deus.

Sem mais insistir sobre o ideal do mestre, expressemos nossos pensamentos sobre nossos livros que, eles também, são como mestres e instrumentos de educação.

O livro é um dos conselheiros da criança. Ele o segue passo a passo. Ensina com, contra, o mestre. Influi consideravelmente sobre a alma do discípulo.

\footnotetext{
${ }^{12}$ M. Bersot, Estudos sobre o século XVIII, 1855, p. 224 ss.
} 
Recordando seu passado, quem dentre vocês não encontra na sua alma a marca profunda de algum livro [280] que deu tal direção a seu espirito, tal ideia predominante na sua vida?

E para falar apenas de influencias inocentes, uma criança hauriu na narração comovedora de naufrágios fabulosos em alguma ilha maravilhosa, o gosto pelas aventuras que ele considera como vocação a enfrentar os perigos do mar. Conhecemos alguns desses marinheiros improvisados que, graças a esse tipo de leituras, se declaram decididos numa idade em que a idade ainda não puderam refletir. Entretanto a ternura inquieta de suas mães se preocupa em torno de seus projetos ameaçadores. Felizmente a experiência intervém para diminuir seus desejos prematuros e estes heróis que se contavam por centenas no início da adolescência, pouco a pouco vêm seus números diminuir. Então aparecem as aptidões reais, as vocações sérias, e a vida toma sua verdadeira direção.

Mas os conselhos da sabedoria o uteis nestas circunstancias poderão sempre produzir frutos em espíritos profundamente perturbados por outros tipos de leituras? Suponham que a razão da criança seja tocada cedo pelo falso, que as noções do que é justo sejam perturbadas no seus espirito, que suas paixões sejam despertadas por imagens suspeitas e que seu coração seja desviado por escritos imorais que circulam com atrativos do mistério entre os alunos de algumas casas, a sabedoria dos pais e dos mestres terá que lutar contra os erros de uma imaginação jovem e imprevidente; o combate será mais sério e a vitória menos assegurada, porque não mais se tratará de discutir tal ou tal forma acidental da vida, mas arrancar a vida de uma direção funesta.

Este perigo pode encontrar-se no próprio ensino e nas leituras de lazer que acompanham o ensino. No ensino, há o elemento pagão que deve ser apresentado com prudência.

Os autores profanos ocupam um grande lugar em nossos programas oficiais, 0 lugar grande demais. O Conselho superior da instrução pública, em 1875 elogiou, embora de um modo imperfeito, os clássicos cristãos, restabelecendo-os no programa do terceiro ano para o grego, e do segundo ano para o latim, colocando-os entre os autores da licenciatura.

A Igreja deseja o ensino misto destas duas literaturas, que têm suas respectivas obras primas e que pertencem a civilizações diferentes; mas ela deseja também [281] 
que o ensino dos autores profanos sejam cercados de precaução preservativas especiais. ${ }^{13}$

Segundo a definição de Platão, a beleza não é o esplendor da verdade? Da mesma forma que o belo, na ordem natural, próprio da civilização pagã, se encontra na primeira literatura latina, o que é belo, sublime, natural e sobrenatural existe em abundancia e resplandece na segunda.

A arte de bem falar, considerado na sua fonte primitiva, não é uma maravilhosa emanação do Verbo de Deus, da Palavra de Deus Pai? Portanto, como poderia se acreditar que o Verbo encarnado, que se dignou dar o dom da palavra as nações que não o conheciam o teria em seguida recusado à Igreja, sua esposa, que ele adquiriu com o seu sangue precioso?

A Igreja nunca excluiu os autores profanos do ensino. Por sua prática como por sua doutrina, ela nos ensinou que eles podem ser os auxiliares da verdade, e os admitiu em concorrência com os autores cristãos.

Não será vantajoso estudar o belo e o sublime por toda parte onde eles se encontram? Deve-se tomar em consideração os gênios, mesmo que não tiver sentindo a felicidade de professar a verdade plena. Homero e Virgílio serão sempre o tema de admiração, enquanto a poesia continuar sendo uma das preocupações do gênero humano; e igualmente enquanto se ensinar os preceitos da eloquência, os modelos indicados serão sempre Demostenes e Cicero.

Tal foi, com toda certeza, o ensino tradicional e constante da Igreja. ${ }^{14}$

"Os livros profanos, dizia São Basílio o Grande, são para os Livros santos o que a folhagem da árvore é para os frutos: ele os precedem, também os cobre e lhes serve de adornos". ${ }^{15}$ E este Santo Doutor admirava, na literatura profana, não só a forma brilhante e a perfeição do estilo, mas a beleza dos exemplos e a elevação dos pensamentos. Entretanto, ele pedia que se fizesse uma escolha dos autores, e que fosse lido assim como as abelhas despojam as flores recolhendo apenas o seu mel. Mas

\footnotetext{
${ }^{13}$ Ver o pronunciamento de Pio IX feito a Dom d' Avanço, de $1^{\circ}$ de abril de 1875.

14 Ver , a esse respeito, a carta endereçada ao Cardeal d' Avanço de 4 de nov. de 1874, que é um verdadeiro tratado sobre o assunto ( livraria da Sociedade de São Paulo)

${ }^{15}$ Discurso sobre a utilidade que os jovens pode tirar da leitura dos autores profanos.
} 
queria, ele também, que fossem os auxiliares da verdade e que os [282]estudassem em conjunto com os autores cristãos.

Seu sentimento foi respeitado na Igreja. "O costume constante da Igreja, lembrava-nos ainda recentemente nosso Venerável Pontífice Pio IX $^{16}$, foi de ensinar o latim aos jovens por meio do estudo misto dos autores sagrados e profanos".

Ninguém duvida de que tenha sido a prática dos primeiros séculos do período dos doutores. Mesmo na idade média, a Igreja, em suas escolas monásticas, conservou o uso dos grandes clássicos pagãos com o dos autores cristãos.

Se Carlos Magno pode reavivar o culto da literatura e produzir, com a ajuda de Alcuin, uma primeira renascença, é porque encontrou em Roma, nas escolas pontificais, tradições, mestres e livros que só teve que transplantar para França, e se sabe que ele trouxe as obras primas das literaturas grega e latina ao mesmo tempo que os principais escritos dos Padres da Igreja.

Nosso grande século clássico, o século XVII, não procedia de outra maneira. Os autores cristãos constituíam o fundamento do ensino. Os autores profanos a ele se acrescentavam, como convém, no final dos estudos.

Sem dúvida, Fénelon não é suspeito de ignorância ou de desprezo dos autores clássicos e sabe-se qual a orientação que ele deus para a educação do Duque de Borgonha. Iniciou com os estudos dos livros sapienciais na Sagrada Escritura, em seguida alguns livros escolhidos de São Jerônimo, de Santo Agostinho, de São Cipriano, de Santo Ambrósio, algumas poesias de Prudêncio e de São Paulino e a História de Sulpicio Severo. ${ }^{17}$ Só depois desses primeiros estudos, ele o iniciou ao estudo das cartas pagãs, ensinando-lhe a utilizá-las para a sabedoria cristã, segundo o exemplo que ele dá em seus Télémaque e seus Diálogos dos Mortos.

É assim que se deveria utilizar a literatura profana, para que sirva à fé e não a destrua.

Hoje estamos longe disso. Quando os estudantes de nossos colégios chagam, eles conhecem melhor a mitologia do que a Historia Sagrada, os fatos e gestos dos deuses do paganismo, do que os dos heróis cristãos.

\footnotetext{
${ }^{16}$ Pronunciamento feito a Dom d' Avanço, $1^{\circ}$ de abril de 1875.

${ }^{17}$ Carta ao Padre Fleyry, citado pelos Arquivos das Missões Científicas, agosto de 1850.
} 
Montalembert o observava na introdução de seu belo livro sobre os monge do Ocidente: "não saímos todos do colégio, dizia ele, sabendo de cor os fatos pouco edificantes da história [283] de Júpiter, e ignorando até o nome dos fundadores das ordens religiosas que civilizaram a Europa e, tantas vezes, salvaram a Igreja"?

Nós reagiremos contra este abuso na medida do possível, sem prejuízo dos programas que os exames nos impõem.

Quanto às leituras de lazer, cuidaremos para que sejam escolhidas com delicada prudência afim de que não pequem por excesso de seriedade nem pela ingenuidade. Não gostamos nem dos espíritos levianos nem dos doutores prematuros. A infância é a primavera da vida. É a idade das flores, antes da idade dos frutos. O desabrochar e o frescor lhe convém antes da maturidade. Muitas vezes Deus dá à criança a beleza, e sua singela bondade é como um perfuma que alegra.

Possamos ser, para com nossas crianças, dignos instrumentos de CRISTO! Possamos corresponder a uma missão tão bela e possuir, com as qualidades do mestre cristão, algo de particularmente elevado, suave e puro que não pode faltar de transmitir a imitação do amável Apostolo tão dedicado às crianças e a união especial com o Sagrado Coração de JESUS, este Coração tão amigo das crianças e tão cheios de graças para eles!

\section{III}

Após ter tratado dos instrumentos da educação. É preciso falar do método.

Uma questão capital no método da educação é a do motivo a dar aos esforços do aluno.

Nós o guiaremos pelo temor, pela afeição, pelo sentimento da honra ou da fé?

Em primeiro lugar, é preciso ter como princípio que a criança precisa de uma orientação poderosa. Quando nasce, ele traz uma mistura de boas e más qualidades, de instintos funestos e de felizes inclinações. 
A revelação de Moisés e a revelação cristã, explica-nos este misterioso combate na alma da criança pela decadência original. Há ali como dois exércitos de inclinações contrárias. Que orientação daremos as tendências para o bem? É necessário que haja um ponto de união nestas forças e como um guia que os reúne. Isto será o pensamento dominador da alma e o que nela vamos imprimir.

Qual será este pensamento ou este princípio dominador que sustentará a alma da criança no trabalho, no dever, na virtude [284], na constância?

Os recursos humanos oferecem espontaneamente o temor, a humilhação ou a honra, e a afeição filial.

O temor humano: não se pode deixar inteiramente de lado a sua ajuda, mas fazer dele o motivo principal da criança, não será amargurar e ressecar seu coração? Não será leva-lo à dissimulação? Com certeza, será apagar os mais generosos elãs de sua natureza, e diminuir a sua alma até dar a todas as suas ações esta finalidade egoísta e sem nobreza, de evitar uma correção.

A humilhação ou a honra: É o princípio que vem em primeiro lugar quando a educação não é fortemente cristã. Este motivo se chama ainda estimulo; e muitas vezes seu verdadeiro nome é a vaidade.

Este princípio tem o seu valor. Muitas vezes é um recurso, mas também permanece superficial e perigoso. Superficial, porque só atinge o aspecto exterior da virtude. Pouco importa, na maioria das vezes, o que a consciência diz, se as aparências estão salvas e se não se atinge a honra. Perigoso, porque este princípio se situa no amor próprio, no egoísmo e na complacência em si mesmo. Que singular preparação para a vida de dedicação, de dever e de generosidade que a sociedade cristã espera desta criança!

Os pais colocam sua confiança num terceiro motivo: a afeição filial. A criança, pensam eles, será fiel ao dever e à virtude para agradar àqueles que ama.

Este sentimento é digno, e gostaríamos que fossem menos esquecido.

Mas será ele sempre suficiente? Não o vemos fracassar habitualmente na idade em que o adolescente consulta mais a sua imaginação perturbada e suas paixões nascentes do que as afeições de sua infância? 
Então o que temos para oferecer a fim de preencher todas essas lacunas? Temos o princípio cristão, e queremos que seja ele que tenha aqui o primeiro lugar.

O pensamento de Deus seu criador e seu mestre, sua onipresença, sua justiça, sua bondade, suas promessas, o CRISTO redentor e sua Graça, a poderosa ação da Eucaristia, e a doce influência das nossas festas cristãs, tais são nossos recursos divinos, que produzirão, disso temos certeza, uma eclosão maravilhosa de piedade cristã e filial, de trabalho, de doçura, de caridade, de força e de constância.

Além da grande questão do motivo a dar ao aluno, existem cem outras questões e métodos.

Deveria se falar da disciplina, dos diversos ramos de estudos: [285] letras, ciências, gramática, literatura, filosofia, línguas antigas, línguas vivas, história, geografia; da classificação destas diversas partes do ensino e do lugar a ser dado a cada uma delas. Seria necessário falar dos procedimentos de educação e de ensino, ensino progressivo, do ensino visual, da psicologia da criança e do desenvolvimento de suas faculdades. Seria preciso distinguir os estudos úteis e os estudos de luxo.

Mas todas estas considerações seriam intermináveis. Temos o método mais simples de lhes fazer conhecer nosso método. Ei-lo: tomaremos no seus conjunto o grande método cristão, aquele que começou depois da paz da Igreja, com os Padres da Igreja grega e os da Igreja latina; aquela que se tornou sucessivamente adaptando-se as necessidades de todas essas épocas, mas conservando sempre seus grandes princípios fundamentais, o método das escolas monásticas e das escolas episcopais da idade média, o método das grandes universidades do século XII, Bossuet, Fénelon, Fleury; aquela que foi codificada pelo sábio e piedoso Rollin no seu tratado dos estudos.

Sim, este belo livro de Rollin, parece-me representar definitivamente o código da educação. Os homens mais importantes da universidade contemporânea, eles mesmos o reconhecem, pelo menos aqueles que não se deixam enganar pela paixão anti religiosa. Villemain e Nisard serão, verdadeiramente testemunhas autorizadas. Vamos escutá-las. "No que se refere a educação, diz Nisard, o Tratados dos Estudos é o livro único, ou melhor, é o livro" 18 .

\footnotetext{
${ }^{18}$ História da Literatura francesa, t. IV, p. 122.
} 
Villemain havia dito: "eu não analisarei esta obra, um pouco negligenciada em nossos dias, como se, depois de Rollin, tivessem descoberto novos métodos para formar a inteligência e o coração. Infelizmente não é assim: nenhum passo foi dado; não haverá nada melhor do que o tratado dos estudos". 19

Sim, é bem a maneira de formar o espirito e o coração que Rollin ensina, e a alí se encontra a finalidade da educação, e seu método é bem o grande método cristão. Gostaria poder analisá-lo e fazer-lhes observar como ele é excelente na arte de ensinar as letras e na arte, mais preciosa ainda, de fazer com que as letras sirvam à virtude. Para a cultura dos costumes e do caráter assim como para o ensino técnico das línguas, da retorica e da filosofia, Rollin disse tudo, e tudo foi dito de uma maneira excelente. [286]

É assim que Chateaubriand o apresenta como professor de história: "a narração do virtuoso reitor, diz ele, é plana, simples e tranquila, e o cristianismo enternecendo sua pena, lhe dá algo que comove as entranhas. Seus escritos revelam o homem de bem, cujo coração é uma festa continua". ${ }^{20}$

Eis nossos mestres e nossos modelos.

É verdade que este senado dos mestres da educação não está mais totalmente em moda. Sua virtude sobretudo incomoda. É preciso procurar na história e tentar reunir alguns irregulares do grande exército dos educadores, fizeram isto em nossos dias e exumaram Rabelais, Montaigne, Ramus, Condorcet, Rousseau e os Convencionais. Até alguns de seus escritos foram colocados nos programas.

É preciso boa vontade para fazer deste conjunto uma escola de pedagogia, chamada progressista, face aos mestres da educação cristã.

Não desespero ver que as buscas conscienciosas de nossos adversários sirvam poderosamente nossa causa.

Os homens de boa fé dirão: os adversários da educação cristã só encontraram estes nomes a opor aos de Basílio o Grande, de Gerson, de Bossuet, Fénelon, de Rollin: eles já foram julgados.

Se houvesse algumas ideias aceitáveis em meio a obscenidade de Rabelais, não seria conveniente ir procurá-las.

${ }^{19}$ Quadro da Literatura francesa no XVII, t. I, p. 226

${ }^{20}$ Génie du Christianisme, III ${ }^{\circ}$ p. livro III 
Quanto aos inovadores da Revolução, a sua leitura muitas vezes é engraçada.

Lequinio, declarando que a literatura é inútil e que é absolutamente supérfluo ocupar-se com este estudo. ${ }^{21}$

Lepelletier, fascinado pelo costume de esparta, propõe a educação comum das crianças dos dois sexos, numa absoluta igualdade. "É preciso, diz ele, que todos tenham um corpo robusto, preparados para o trabalho. Para isto, receberão uma alimentação frugal, sem carne nem vinho, e eles serão exercitados para cultivar a terra. Se não houver ao seu alcance terra para cultivar, eles irão nos caminhos espalhar ou amontoar pedras". É suficientemente democrático. Aliás, não se lhes falará de religião positiva. É como escutar Rousseau, e hoje ainda, Michelet extasiava-se diante do projeto de Lepelletier que chamava "a revolução da infância". [287] e o "Evangelho da pedagogia". ${ }^{22}$

É Saint-Just, um candidato do departamento de Aisne, que quer igualmente que as crianças até a idade de dezesseis anos sejam educadas às custas do Estado. É verdade que sua educação não será dispendiosa. Sua alimentação será feita de frutas, legumes, leite. Pão e água. Seu traje será de pano de algodão em todas as estações. ${ }^{23}$

É Barrère, pedindo para se desembaraçar dos livros, "de toda aquela papelada que atrapalha o gênero humano".

É Fourcroy, ele mesmo, Fourcroy o químico, pedindo que não houvesse mais colégios. "Instruir, é tiranizar; segundo ele, era preciso deixar a criança livre".

É Cofinal, respondendo a Lavoisier, que defendia as ciências: "cale-se, a Republica não precisa de química". ${ }^{24}$

É Bouquier, apresentando, com os aplausos da Convenção, um plano que afastava para sempre toda ideia de estudos especulativos e científicos. "As mais belas escolas, dizia ele, as mais úteis, as mais simples são as sessões dos comícios. A Revolução, ao estabelecer festas nacionais, ao criar sociedades populares, clubes, colocou em toda parte fontes inesgotáveis de instrução. Não vamos, acrescentava ele, substituir esta organização simples e sublime, como o povo que a criou, por uma

\footnotetext{
${ }^{21}$ Monitor de 16 de julho de 1793.

${ }^{22}$ História da Revolução, t. IV

${ }^{23}$ Obras políticas, Instituições Republicanas

${ }^{24}$ Ver o Monitor de outubro a dezembro de 1793.
} 
organização artificial, baseada em estatutos acadêmicos que não devem mais infectar uma nação gerenerada".

E seu projeto foi votado no dia 19 de dezembro de 1793. (29 frimaire ano 11).

Eis muitas ideias novas, às quais educadores cristãos não tinham pensado.

Mas, tudo isto foi bastante para nos divertir.

Mesmo se guardamos em substância o grande método dos antigos, não queremos rejeitar os melhoramentos e as mudanças que o tempo e a experiência nos trouxeram.

Os progressos das ciências exigem que lhes sejam dados um maior lugar na educação.

A história, enriquecida pelas descobertas orientais e pelo estudo das fontes, deve ser ensinada mais completamente.

A língua latina, não sendo mais como antigamente a língua do direito, da medicina e da filosofia, não é mais necessário saber escrevê-la e falar; [288] basta saber compreender suas obras primas.

A facilidade das relações com o estrangeiro nos impõe o conhecimento das línguas vivas.

O desenvolvimento da indústria deu lugar à criação de um novo sistema de estudos, que se situa entre o ensino primário e as humanidades.

A difusão da gravura fornece o novo recurso para a utilidade e a ilustração de nossos livros escolares.

Nada queremos desprezar das mudanças que se impõem e nada negligenciar destes progressos. Organizaremos o quadro comum dos estudos atuais, enobrecendo-os com os meios próprios da educação cristã e completando-os na medida em que a rapidez do tempo o permitir.

Em resumo, sem desconhecer as exigências do nosso tempo para formação do espirito de nossas crianças, seguiremos para a formação de seu coração, o método cristão tradicional que Rollin resumia nestas grandes linhas:

Estudar o caráter das crianças para bem orientá-las; fazer-se amar por elas tanto quanto temer; falar lhes de razão; acostumá-las a serem sinceras; formá-la à polidez; 
tornar os estudos amáveis; e sobretudo fazer reinar neles, a piedade que resume e contém todas as boas disposições do coração.

Se realizarmos isto, tenho a confiança de que teremos bem merecido de vocês, da França e de Deus.

Finalmente, senhores, toda esta teoria tão sedutora sobre a educação cristão, sua finalidade, seus instrumentos, seu método, não provém de uma ilusão? A educação cristã produz os frutos que prometemos? A tentativa foi feita, correspondeu a esta concepção?

Gostaria de poder ler nas almas, ou antes, gostaria de poder abrir diante de vocês os horizontes para que vocês compreendessem melhor os efeitos da educação cristã. Gostaria de poder lhes enumerar estes efeitos de modo bem imparcial. Talvez o melhor será, afim de afastar toda desconfiança de parcialidade, deixar falar testemunhas.

Existem almas que parecem ter um dom particular para se manifestar, são as almas dos poetas. A Providência [289] nos fez encontrar o quadro das impressões de um poeta sentimental que conheceu a dupla educação de um colégio indiferente e de uma casa religiosa. Eis duas páginas que são de Lamartine, vocês poderão julgar. ${ }^{25}$

Iniciemos pelo colégio indiferente:

"Semelhante, diz ele, a estes filhos de bárbaros que eram mergulhados ora na água fervente ora na água geladas afim de tornar sua pele insensível aos efeitos dos climas, a criança foi jogada na incredulidade e na fé. Ela entra num colégio divido entre o espirito e as tendências. Precisaria que ela tivesse duas almas, ela só tem uma. Ela é sacudida, rasgada em sentido contrário; a perturbação e a desordem penetram suas ideias, há nelas um pouco de fé e um pouco de razão; sua fé se apaga, sua razão esfria, sua alma resseca e seu entusiasmo se muda em indiferença e em desanimo".

Não é a história de muitas almas?

\footnotetext{
${ }^{25}$ Citado pelo Padre Monfat, Educação, p. 104.
} 
Eis agora a impressão que o poeta guardou da educação cristã numa casa religiosa.

“Toda a arte de nossos mestres consistia em nos interessar no sucesso da casa e a nos guiar pela nossa própria vontade e nosso próprio entusiasmo. Um espirito divino parecia animar com um mesmo sopro os mestres e os discípulos. Todas as nossas almas tinham reencontrado suas asas e voavam com um elã natural para o bem e para o belo. Os mais rebeldes, eles mesmos, eram levantados e arrastados pelo movimento geral. É ali que vi como se podia educar homens, não pelo constrangimento, mas inspirando-os".

Como este quadro é sereno e radioso, e como contrasta com a sombra do primeiro!

Depois do testemunho do poeta, eis a afirmação do bom senso. Eu dou a palavra a um Bispo anglicano: a Inglaterra é a terra clássica do senso prático. Ele fala da educação da América, país das experiências e das invenções. Ali foram criadas escolas neutras, ou seja, escolas sem Deus.

O nome é pitoresco. Este nome poderia servir para muitas casas de educação francesas, onde a religião tem tão pouca vida que estas casas poderiam ser classificadas de neutras.

Que dizia portanto este Bispo anglicano: "Que gostaria mais, ver o islamismo ser ensinado nos internados da sua diocese do que ver implantar nela, escolas onde a religião é completamente banida". É a maneira [290] de expressar a sua apreciação sobre os resultados das escolas sem Deus na América.

Eis agora o testemunho do homem de experiência: do homem de negócios e do progresso. Eu consulto o presidente da comissão francesa na exposição de Filadélfia em 1876. O testemunho é bastante recente, a testemunha bastante ligada ao movimento industrial e cientifico.

O que ele diz no seu relatório sobre o ensino na América? Ele fala da decadência das escolas neutras e da superioridade incontestável, da prosperidade crescente das escolas católicas.

As afirmações dos grandes espíritos estão de acordo com aquelas do senso comum e da experiência. 
Vocês aceitarão como testemunhas suficientemente variadas e autorizadas, o comte de Maistre, M. Thiers e M. Guizot? Joseph de Maistre representando a filosofia católica, M. Guizot representando os cultos dissidentes e M. Thiers representando as ideias chamadas modernas. Eis o que eles dizem: "todo sistema de educação que não se baseia na religião, diz Joseph de Maistre, cairá num abrir e fechar de olhos ou irá envenenar o Estado. Se a educação não for devolvida aos sacerdotes, e se a ciência não vem em segundo lugar, os males que nos aguardam são incalculáveis: seremos embrutecidos pela ciência sem Deus, é o último grau do embrutecimento".

M. Guizot dizia: "não se acredita bastante que a instrução nada é sem a educação. A isso é preciso logo acrescentar: não há educação sem religião. A alma não se forma e nem se regula senão em presença e sobre o poder de Deus que a criou e que a julgará”.

Finalmente, para encerrar a lista dos testemunhos que poderíamos prolongar indefinidamente, guardaremos a palavra de M. Thiers, que expressa seus sentimentos sobre a educação: a escola só será boa se ela permanecer na sombra da sacristia". ${ }^{26}$

O que o testemunho acaba de afirmar, a razão não poderia fazê-lo?

A educação religiosa não é a cultura das faculdades mais elevadas do homem, a civilização da inteligência e do coração?

"Qual seria, perguntava um dos eloquentes oradores do púlpito de Notre Dame, ${ }^{27}$ o povo cuja religião não teria reprimido na infância os instintos depravados? Poderia ter ciência, mas [291] não teria fé, inteligência, mas não teria princípios. Ele conheceria o ódio, não o amor; a revolta, não a obediência; o desprezo, não o respeito; a volúpia, não a castidade. Seria capaz de enriquecer-se, não de se dedicar. No seu conjunto seria um povo egoísta, cobiçoso, volutuoso, sem amor, sem generosidade, numa palavra, um povo mal educado".

Vão num pensionato, num colégio onde a religião é negligenciada, afastada como um comercio inútil, ou mesmo, infelizmente, desprezada e insultada: Que visão desoladora! Que feiura moral numa idade em que a vida tem seus mais belos encantos! Procurem ali crianças que combatem seu egoísmo, seu orgulho, sua independência, sua

${ }^{26}$ Discursos políticos, 1850.

${ }^{27}$ O Padre Felix, Conferência sobre a Educação. 
cólera, sobretudo sua vontade; vocês não encontrarão: a criança sem religião não domina suas paixões.

Ali vocês verão as crianças já incrédulas, talvez já impiedosa; e aquele jovem ímpio, é altaneiro, orgulhoso, revoltado, insolente, grosseiro, volutuoso, mau, quase bárbaro.

A educação, que não é francamente cristã, deixa o coração sem abertura, sem expansão e sem caridade.

Ela não tem a força e a graça para cultivar a mais bela das virtudes, a pureza, virtude eminentemente cristã, uma destas virtudes reservadas, com dizia Lacordaire, virtudes que são a gloria da Igreja.

Com efeito, é preciso que o mestre seja um homem de Deus para fazer uma guarda santa em torno do coração da criança onde habita uma pureza ignorante e cândida, ou em torno do coração do adolescente, que contém a tempestade e já conhece a honra de uma castidade provada.

Só o homem de Deus saberá, na sua incansável e inteligente dedicação, olhar ou escutar para afastar o inimigo que ameaça; abrir os olhos para ver um sinal, os ouvidos para escutar uma palavra reveladora, afastar com a mão discreta o veneno que se esconde no livro, numa amizade perigosa; numa palavra, zelar com uma solicitude materna ou sacerdotal, e salvaguardar, com a pureza, todas as virtudes que formam a graciosa auréola da criança cristã.

Portanto, é assim que a razão está de acordo com a experiência para proclamar que a educação cristã deve presidir aos primeiros anos da vida se se quer orientar esta vida para o seu verdadeiro ideal e se se quer obter dos espíritos verdadeiramente esclarecidos, caracteres enérgicos, corações generosos, homens de fé e de ações, capazes de todos os grandes pensamentos, de todas as resoluções vigorosas, de todas as dedicações e de todos os sacrifícios para a religião e a pátria.

Eu espero que será a consolação do Bispo de Soissons, nosso tão digno e tão venerável pontífice, ter estabelecido com a ajuda dedicada do seu vigário geral e sem se deter diante de nenhum obstáculo, esta casa de São João, que se esforçará, sem deixar de lado os estudos, em transmitir de geração em geração a educação cristã e a ciência da salvação. 
Agora, queridas crianças, nós as entregamos a seus bem amados pais. Vão reencontrar a vida em família, e com ela o repouso e o desabrochar do coração.

Os corações das crianças se abrem para sua mãe. Sejam confiantes para com suas mães. Enquanto seus corações e o delas estiverem de acordo, nada terão que temer.

Nós as entregamos com confiança à guarda de Deus que as ama; à guarda de seus pais que são os seus anjos visíveis na terra; à guarda de suas consciências que Deus ilumina e fortifica.

Adeus por algumas semanas, sejam felizes, sejam comportados, sejam prudentes.

Nossa afeição para com vocês nos dita esses últimos conselhos; suas boas disposições nos asseguram de sua fidelidade. 